\title{
An unusual cause of a mediastinal mass
}

\author{
Shaemala Anpalakhan, ${ }^{1}$ Ratna Alluri, ${ }^{1}$ J Graham Douglas, ${ }^{1}$ Lutfi Kurban ${ }^{2}$
}

${ }^{1}$ Respiratory Unit, Aberdeen Royal Infirmary, Aberdeen, UK ${ }^{2}$ Deparment of Radiology, Aberdeen Royal Infirmary, Aberdeen, UK

\section{Correspondence to} Dr J Graham Douglas, graham.douglas@nhs.net
To cite: Anpalakhan $S$, Alluri R, Douglas JG, et al. BMJ Case Reports Published online: [please include Day Month year] doi:10.1136/ bcr-2012-007978

\section{SUMMARY}

Our case report describes an unusual cause of a mediastinal mass. The patient is a current smoker with a background of neurofibromatosis (NF) type 1 who presented with a right apical mass. Initial investigations suggested a probable malignant cause. The final diagnosis was one of a haematoma from a ruptured thyrocervical aneurysm. The association between neurofibromatosis and vascular aneurysms is an often unrecognised but documented phenomenon. We would like to raise an awareness of this infrequent presentation, as it is associated with a high mortality and may be prevented by early diagnosis.

\section{BACKGROUND}

We would like to raise awareness of this infrequent presentation, as it is associated with a high mortality and may be prevented by early diagnosis.

\section{CASE PRESENTATION}

A previously fit 39-year-old male smoker with a history of neurofibromatosis (NF) type 1 presented with a 2 week history of progressively worsening sensori-motor symptoms of the right arm, right neck vein distension and weight loss. Diagnosed with neurofibromatosis type 1 in 2011 , he had no significant medical history of note and was not on regular medication. He did not have a family history of neurofibromatosis. General examination revealed multiple neurofibromas across the trunk and upper arms, and multiple café-au-lait patches with axillary freckling. His trachea was slightly deviated to the right and he had reduced breath sounds at the right base and apex. Neurological examination demonstrated a right-sided Horner's syndrome and sensori-motor weakness in the distribution of T1/T2.

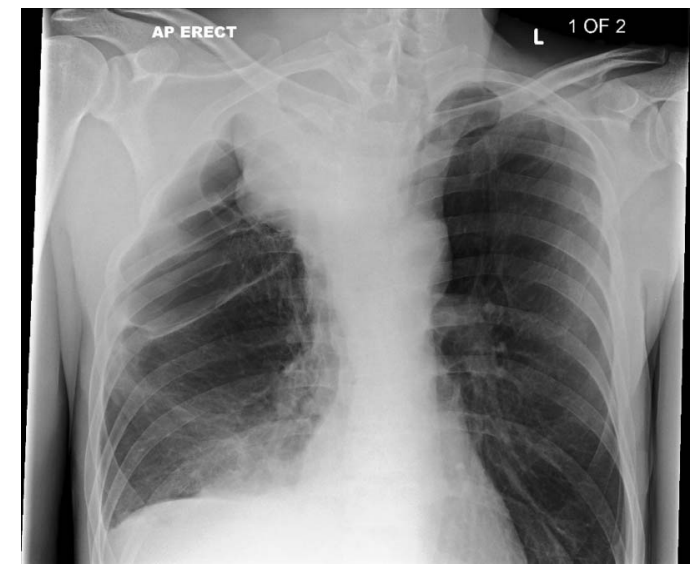

Figure 1 Chest x-ray showing large right upper zone opacity with evidence of volume loss.

\section{INVESTIGATIONS}

His chest $\mathrm{X}$-ray showed a right apical mass (figure 1). Full blood count showed normocytic anaemia. His renal function and liver function tests were normal. CT scan confirmed a right apical mass and an associated pleural effusion. An ultrasound-guided biopsy of the mass demonstrated a neurofibroma. Pleural fluid aspirate did not demonstrate malignant cells but was heavily blood stained. The clinical history and presentation suggested an underlying malignant cause and hence a surgical biopsy of the mass was requested. An MRI scan was undertaken preoperatively (figure 2), which demonstrated a $9 \times 7 \mathrm{~cm}$ mass and a $2 \times 3 \mathrm{~cm}$ thyrocervical aneurysm at the superior aspect of the mass (figure 2). CT angiogram confirmed the aneurysm.

\section{DIFFERENTIAL DIAGNOSIS}

The differential diagnosis at this stage included a benign neurofibroma, possible malignant transformation of a pre-existing neurofibroma or a primary lung tumour with an incidental finding of a thyrocervical aneurysm.

\section{TREATMENT}

The patient underwent coil embolisation for the aneurysm.

\section{OUTCOME AND FOLLOW-UP}

For the mass he proceeded to thoracotomy. Intraoperatively the radiologically visible mass was found to be a large mediastinal haematoma. The decision was made not to evacuate the haematoma or proceed with further biopsies.

\section{DISCUSSION}

NF type 1 is an autosomal-dominant genetic disorder involving chromosome $17 .^{1}$ It has a prevalence of 1 in 3000. Fifty per cent of cases arise

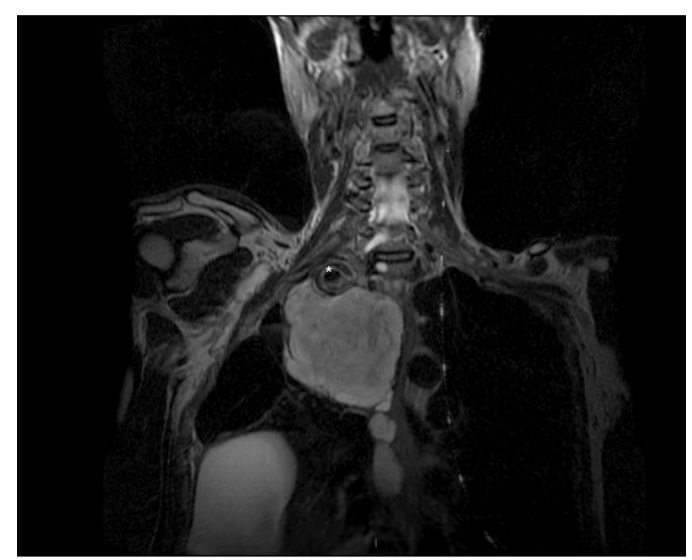

Figure 2 T1-weighted MRI image showing the thyrocervical aneurysm and associated haematoma. 
from spontaneous mutations. It is a disorder with variable expressivity. It is characterised by neuroectodermal or mesodermal tumour growths ${ }^{2}$ like neurofibromas, optic gliomas, hamartomas and their associated complications. Neurofibromas can undergo malignant transformation.

Arterial stenosis and arterial aneurysms in NF are a less recognised association. Incidence is reported at 3.6\%. ${ }^{3}$ Most involve the renal artery. ${ }^{4}$

Involvement of vessels within the mediastinum is rare. These aneurysms usually present as incidental findings or as complications secondary to rupture or bleeding. Thus, so far there have been two case reports of thyrocervical artery aneurysm rupture associated with neurofibromatosis causing spontaneous haemothorax. ${ }^{45}$ Current management options include conservative management, coil embolisation and open surgery. Operative mortality is high at $33 \%$ and overall mortality is $36 \%{ }^{4}$

In conclusion, vascular aneurysms and stenoses in NF is a recognised association with a high mortality. Greater clinical awareness will aid early diagnosis and investigation thereby preventing fatal outcomes.

\section{Learning points}

- There is an association between aneurysms and neurofibromatosis.

- Early recognition of this association prevents fatal outcomes.

- Current management options include conservative management, coil embolisation and open surgery.
Competing interests None.

Patient consent Obtained.

Provenance and peer review Not commissioned; externally peer reviewed.

\section{REFERENCES}

1 Friedman JM. Epidemiology of neurofibromatosis type 1. Am J Med Genet 1999:89:1-6.

2 Hirsch NP, Murphy A, Radcliffe JJ. Neurofibromatosis: clinical presentations and anaesthetic implications. Br J Anaesth 2001;86:555-64.

3 Fedoruk LM, English J, Fradet GJ. Spontaneous hemothorax and neurofibromatosis: a review of a lethal combination. Asian Cardiovasc Thorac Ann 2007;15:342-4.

4 Al-Jundi W, Matheiken S, Abdel-Rehim S, et al. Ruptured thyrocervical trunk anuerysm in a patient with type I neurofibromatosis. EJVES Extra 2011;21:e10-12.

5 Teitelbaum GP, Hurvitz RJ, Esrig BC. Hemothorax in type 1 neurofibromatosis. Ann Thorac Surg 1998;66:569-71.

Copyright 2013 BMJ Publishing Group. All rights reserved. For permission to reuse any of this content visit http://group.bmj.com/group/rights-licensing/permissions.

BMJ Case Report Fellows may re-use this article for personal use and teaching without any further permission.

Become a Fellow of BMJ Case Reports today and you can:

- Submit as many cases as you like

- Enjoy fast sympathetic peer review and rapid publication of accepted articles

- Access all the published articles

- Re-use any of the published material for personal use and teaching without further permission

For information on Institutional Fellowships contact consortiasales@bmjgroup.com

Visit casereports.bmj.com for more articles like this and to become a Fellow 